\title{
Cine sin Autor, la salud imaginaria de la sociedad
}

\author{
Gerardo Iván TUDURÍ ROLDÁN ${ }^{1}$ \\ gerardotuduri@gmail.com
}

Recibido: 23/09/14

Aceptado: 23/10/14

\section{RESUMEN}

El cine ha comenzado una segunda historia a partir de la transformación digital. Estamos ante la posibilidad de democratizar la producción de cine al conjunto de la sociedad pero para eso se necesita cambiar la concepción que hasta ahora hemos tenido de "lo cinematográfico" en todos sus procesos. Democratizar la producción significará un cambio cualitativo importante en la salud imaginaria de la sociedad en su conjunto. El trabajo del colectivo Cine sin Autor busca allanar el camino.

Palabras clave: imaginario social, dispositivos de producción, narrativas comunes, ecosistema cinematográfico, suicidio autoral, sinautoría.

\section{Referencia normalizada}

TUDURÍ ROLDÁN G. I. (2014). "Cine sin Autor, la salud imaginaria de la sociedad". En Arteterapia: Papeles de arteterapia y educación artística para la inclusión social Vol.: 9. Páginas 309325. Madrid.

\section{SUMARIO}

Una maquinaria fascinante. Operativas sociales de preproducción, autonomía individual y creación de colectividad. La película como despertar organizativo y horizonte utópico útil. El guión. La generación de narrativas comunes. La ruptura de la soledad imaginaria. Despertar creativo de la autonomía personal. Crisis y reordenamientos de los roles sociales. La escritura fílmica en común. Responsabilidad común sobre la gestión y el uso. Conclusiones. Referencias bibliográficas.

\section{Authorless Cinema, imaginary health of society}

\begin{abstract}
Since the digital transformation cinema has started a second history. We now have the possibility to democratize cinematographic production for society as a whole. But for this to happen we need to change our conception of what we considered "cinematographic" in all it's processes. Democratizing production will mean an important change of quality concerning the health of imaginary for society as a whole. The work of the autherless cinema collective eases this path
\end{abstract}

${ }^{1}$ Cineasta, escritor. Es uno de los fundadores del Colectivo Cine sin Autor que lleva 7 años desarrollando experiencias de cine democrático en Madrid y Toulouse. Autor de los dos Manifiestos que sustentan la práctica. 
Key words: Socio-environmental integration, art therapy, educational processes, environmental education.

\section{CONTENTS}

A fascinating machinery. Social operatives of preproduction, individual autonomy and collective creation. Film as an organizational awakening and useful utopian horizon. The generation of common narratives. Rupture with imaginary solitude. Creative awakening of personal autonomy. Crisis and reordering of social roles. Cinematographic writing in community. Common responsibility over management and explotation. Conclusions. References.

\section{Una maquinaria fascinante}

Los inventores del cine, empírica e inconscientemente, han proyectado al aire libre las estructuras de lo imaginario, la prodigiosa movilidad de la asimilación psicológica, los procesos de la inteligencia. Todo lo que se puede decir del cine vale para el espiritu humano; su poder a la vez conservador, animador y creador de imágenes animadas. El cine hace comprender no solamente el teatro, poesía, música, sino también el teatro interior del espíritu: Sueños, imaginaciones, representaciones; ese pequeño cine que tenemos en la cabeza... Todas las diastasas del espiritu están ya en acción en el mundo de la pantalla. Son proyectadas en el universo y traen de él las sustancias identificables. El cine refleja el comercio mental del hombre con el mundo."(Morin, 2011)

De un dispositivo en sus inicios sencillo, el cine fue convirtiéndose en uno de los mayores y más complejos sistemas sociales de exteriorización y visionado público de los imaginarios humanos. Aun así, lo que ha primado desde su origen han sido organizaciones muy minoritarias de personas que fabricaron y gestionaron películas, para que unas mayorías de personas las vean.

El Cine permite que la imaginación humana oculta pueda hacerse pública, compartirse, evidenciarse mediante flujos y secuencias narrativas audiovisuales de la más diversa índole, que abandonando el territorio de la subjetividad privada y circular (exhibición mediante)pasan a ocupar el territorio de lo común.

Sabemos que cualquier disciplina artística o modo de expresión lo hace, pero el cine tomó desde el principio un modelo de organización acorde a las necesidades industriales y empresariales de sus propietarios.

Un conjunto de tareas, todas ellas, excitantes, estimulantes, creativas, desafiantes, no producen los mismos impactos para quien lo produce, que para quienes lo ven.

Estrictamente, no podemos afirmar que el Cine haya posibilitado exteriorizar los mundos imaginarios de la sociedad. Dada la configuración de negocio espectacular que adoptó en su forma hegemónica, nunca ha sido reflejo de las sociedades sino de aquellos grupos propietarios de los medios de fabricación y gestión de las películas. 
El resto, esa gran mayoría, solo ha asistido a una actividad secundaria de espectador que, como mucho, ha ido apropiándose de esos contenidos y formas audiovisuales para posicionarse o identificarse, para empatizar o rechazarlos o, incluso y ahora, para remezclarlos en sus propias creaciones.

Pero no se puede decir, materialmente hablando, que los y las espectadores hayan producido activamente el cine. Más bien han mantenido y desarrollado la actividad psíquica del perceptor y el comentarista.

Ni siquiera, este espectador al que se ha dirigido el cine, es siempre y de forma permanente espectador, sino que solo lo es intermitentemente durante el tiempo que ve la película. Luego se convierte en un recordador, rumiador, analizador, comentarista de cine, pero deja de ser activamente espectador.

Recién en las últimas décadas, el espectador se ha ido constituyendo como productor efectivo de imágenes audiovisuales propias, que al fin y al cabo siempre serán hijas del cine.

La sociedad de esta primera década del siglo XXI es una sociedad en plena transformación, configurada cada vez más como usuaria-productora a la par que espectadora.

Es en este contexto de cambio vertiginoso cuando en Cine sin Autor enunciamos hace ya unos cuantos años un derecho: el derecho que tiene cualquier persona a crear, fabricar su propia representación fílmica.

En definitiva, el derecho a que la actividad cinematográfica se incorpore como herramienta fundamental para el desarrollo de una buena salud de la imaginación.

Cuando queremos mejorar o mantener nuestro estado físico, encontramos multitud de propuestas y posibilidades sociales para hacerlo. Regímenes, planes de ejercicios, gimnasios, centros especializados, etc. Vamos allí y nos hacemos o nos recomiendan un plan de actividades para sostener y mejorar nuestra salud física o sencillamente nos hacemos un plan en nuestra casa con la información disponible.

Resultaría extraño imaginar una sociedad donde el cuidado y mantenimiento de la salud física fuera un asunto solo reservado para una minoría de atletas o deportistas de élite. Igualmente extraño sería que a las grandes mayorías solo se les reservara el rol de mirar a esos deportistas exhibir su estado atlético pero sin derecho a hacer uso de la información para sacar beneficio propio. Más inadmisible sería que toda la información sobre la salud y los beneficios del deporte y el atletismo estuvieran reservados también para esa élite profesional. Todos entendemos que la salud física deber integrarse como valor educativo, independiente de que tales o cuales alumnos vayan a dedicarse a la carrera atlética de manera profesional.

Pero no pasa igual con el Cine. La más fascinante maquinaria que tiene la capacidad de abordar, organizar y exterioriza nuestros imaginarios ha sido utilizada casi de manera privada por algunos pequeños sectores. No hay centros especializados vinculados a la producción fílmica, volcados a la atención y mantenimiento de las facultades imaginativas de la gente común. 
El conocimiento cinematográfico y sus beneficios sigue siendo el reducto de unos privilegiados.

Pero históricamente, bien podemos decir que el cine, sí ha desarrollado sus centros especializados de producción (fábricas, productoras, etc.) y sus centros especializados en percepción del cine (las salas). Ese fue siempre el contrato cinematográfico social, el pacto entre productores y espectadores. Nosotros lo fabricamos y ustedes pagan para verlo.

Los centros de producción ya sabemos que siempre han sido lugares privados, de muy difícil acceso y cuyas actividades son ocultas.

Las salas de cine en cambio, se constituyeron como el lugar público donde la gente podía y puede ir a ver los productos acabados.

Hasta la aparición de la era digital, el cine se estructuró fundamentalmente sobre esos centros privados de exhibición de concurrencia masiva que fueron las salas, o iniciativas más minoritarias como los cineclubs.

Nuestro enfoque y actividad de lo cinematográfico, como colectivo, consiste en abrir el cine a un proceso profundo de democratización en todas sus fases de producción y gestión, con el objetivo de que aquellos beneficios generales que origina el cine en su etapa de producción, se abran a cualquier persona y grupos de la sociedad.

\section{Un ecosistema cinematográfico sano, diverso}

Generalmente no se habla de ello, pero la mayor parte de lo que se dice y se analiza del cine tiene que ver con el espacio diegético de las películas. Como si éstas se hicieran solas. Como si aparecieran en una sala conducidas por un fantasma que en la oscuridad las hace discurrir por la pantalla. Como si no necesitaran ni medios, ni personas, ni saberes para producirse. Como si sus formas sociales de producción no determinaran las formas estéticas.

En este artículo queremos dejar expuesta la idea de que el cine es un entorno de producción que mucho puede ayudar a la salud imaginaria y emocional de las personas en su proceso de fabricación más allá de aquellos que derivan del acto de su percepción, del acto de ver películas.

Es bastante constatable el hecho de que la estructuración productiva que tuvo el cine supuso que la mayoría social ha sido estimulada en su función espectadora y que no es fácil socialmente desprogramarse de concebir el cine como esa sucesión inabarcable de películas a nuestra disposición.

Nuestro trabajo desde Cine sin Autor tiene que ver con este cambio paradigmático que llevamos presenciando sobre todo en la última década y media. En el momento actual, lo más interesante que está pasando en el Cine no es que tengamos un banco inabarcable de películas a disposición, que obviamente es una situación excitante y de gran utilidad, sino el que el estado tecnológico alcanzado nos ha abierto la posibilidad más que real de democratizar su producción y su gestión y, por lo tanto, los diversos beneficios e impacto que esto acarrea.

En este artículo preferimos hablar de esta situación tan nueva como inédita en la historia del cine y por tanto de la sociedad. 
¿Qué beneficios produce la fabricación y gestión de películas?

Recorramos para quien no esté familiarizado los pasos tradicionales que sigue la fabricación fílmica.

a. Alguien tiene una película en la cabeza, un flujo de imágenes y sonidos con una narrativa, no necesariamente con una historia pero sí con una narrativa.

b. Alguien la escucha y decide apostar invirtiendo en ella.

c. Se genera una organización para esa producción o se utiliza una que ya existe. Una productora. (Estructuras sociales jerarquizadas, con un sistema bien definido de poder y autoridad concentrada en sus figuras propietarias y directivas).

d. Se buscan todos los recursos necesarios que requiera la idea.

e. Se plantea un guion, una guía detallada de lo que se prevé va a ocurrir en la película. (Generalmente es el trabajo de uno o varios guionistas que necesitará la aprobación de los responsables e inversores)

f. Se comienza la realización propiamente dicha. (Una organización especifica de gente especializada en los diferentes oficios del cine-actores y actrices, iluminadores, cámaras, sonidistas, etc.).

g. Se planifica el rodaje y se efectúa. Escena por escena. Actores y actrices interpretan y el resto de técnicos registran el sonido y la imagen de esa representación.

h. Un montador o varios hacen el montaje de la película.

i. El director y los responsables económicos van dando su visto bueno.

j. Se hace luego la postproducción. Un ajuste profundo de acabado de imagen y sonido, banda sonora, gráficos, mezclas finales, etc.

$k$. Otro grupo de gente comienza o ya trabajaban en los intentos de explotación comercial, o en su defecto de su circulación.

l. Se distribuye en las salas en caso de encontrar distribuidora interesada.

m. La gente acudirá a la sala, pagará para ver la película y los propietarios comprobarán si ha sido una buena inversión.

n. Productores, Distribuidores, Inversores y propietarios de salas en general recaudan el dinero y buscan sacar un beneficio que les permita la continuidad de su actividad.

Digamos que en un brevísimo y muy simplificado resumen esos son los pasos que el viejo esquema del cine hacía o hace aún dentro del sector profesional.

Como se puede apreciar, la producción de una película integra a un grupo amplio de profesiones y actividades especializadas (tened en cuenta que estos procesos aunque son estándares varían en cada caso).

Los beneficios humanos de la producción y gestión cinematográfica, que son muchos, afectan a ese conjunto de personas que recorrerán una variedad de actividades: creativas, técnicas, administrativas, organizativas, financieras, estéticas, etc. A través de ellas se hará la exteriorización de un imaginario creado por el guionista, o el director si también es guionista o algunas pocas figuras que 
determinarán el contenido y forma del film. En los intensos tiempos de fabricación y gestión, imaginad los saberes diversos, gestión de emociones y sentimientos, puestas en escenas, diálogos, aprendizajes, planificaciones, ejercicios contables y toda la serie de actividades que desencadena un proceso de esas magnitudes.

Aidelman y De Lucas (2010) citan a Jean Luc Godard que resumía muy bien este concepto en unas declaraciones del año 2002:

Para mí, todavía hoy, el cine es una metáfora de la sociedad. Si estudiamos una célula de cine -cómo se hace una película, entre tres o cuatro, o cuarenta o cincuenta, con dinero, mujeres, hombres, patrones, secretarias, chóferes, empleados- tenemos entonces una especie de metáfora, pero viva. Vemos cómo funciona una pequeña sociedad, es una célula. Como en el estudio de una célula en biología, tenemos todos los componentes psicológicos, biológicos, artísticos, sexuales, novelescos... Esas sociedades del cine son muy interesantes porque viven aproximadamente un año: al principio, dos o tres personas se reúnen, el número aumenta con el rodaje, después disminuye durante el montaje y, al final, la gente no se ve más.

La propuesta del Cine sin Autor avanza en el diseño de un modelo de producción social que pretende ir más allá de esta situación que plantea Godard. Creemos que la producción de cine puede abandonar ese carácter de metáfora de la sociedad, de mera muestra, para que pase a constituirse como dinámica habitual de la sociedad en sus estructuras e instituciones educativas, asociativas, terapéuticas y en cualquier tipo de organización humana.

En cada experiencia buscamos que esa microsociedad en torno al cine se active aunque no siempre lo alcancemos como quisiéramos.

Para alcanzar estos objetivos, hemos tomado las operativas de producción y gestión cinematográficas que, como decíamos, eran privadas y minoritarias y las hemos re-ritualizado como operativas sociales, abiertas, de fácil acceso para cualquiera. Una microsociedad donde cualquier persona ejerza su derecho a la libre representación fílmica, un entorno para el cultivo de la buena salud imaginaria ciudadana.

Para ello hacemos en la práctica desplazamientos de la autoridad y el poder del viejo esquema con que se desarrollaba el cine: donde había jerarquía, elitismo, actividad privada, exclusividad y diferenciación de clase entre técnicos-artistas y la gente común, proponemos horizontalidad, actividad pública, igualdad de valor social entre sus participantes, igualdad de autoridad para decidir, protagonismo propio de las personas, dirección asamblearia-rotativa, desactivación de la diferencia de poder entre profesionales y no profesionales.

Los diferentes saberes no otorgan en nuestra filosofía cultural ni autoridad, ni poder diferente sobre las continuas tomas de decisiones que se suceden en un proceso cinematográfico. 


\section{Operativas sociales de preproducción, autonomía individual y creación de colectividad}

La Pre-producción, que en el Cine convencional consiste en la planificación y el plan de viabilidad de una película, en la metodología de Cine sin Autor se redefinen como un encuentro social entre el equipo de realización (saberes y medios de hacer cine) y las personas no especializadas.

Estas serán abordadas en sus propios contextos, en sus propios Plató-Mundos.

No existe en nosotros, el equipo de realización, una intención de "inclusión social" de esas personas extrañas a la actividad tal como se concibe generalmente: alguien para el que se crean mecanismos de incorporación a algo que ya funciona en sí mismo. En todo caso, quienes nos debemos incluir en los lugares y la vida de la gente para constituirnos como colectividad junto a ellas, somos nosotros.

Para entender esta postura, debemos aclarar nuestro concepto de Sinautoría, motor de nuestra producción artística. La Sinautoría es una postura frente a la producción cultural activada sobre la constante pregunta que vuelve una y otra vez sobre el colectivo que produce: ¿quién ejerce el poder y la autoridad ahora, en esta escena, en el rodaje, en la toma de palabra, en los montajes, en las decisiones en general?

La Sinautoría emerge en el marco de la Política de la Colectividad que creemos imprescindible para dar un cambio paradigmático en la concepción social de lo cultural. Aunque no está implementada aún en el terreno de la normativa social, se instaura por la vía de los hechos. Donde aplicamos la Sinautoría, comienza a operar otra política, la de la colectividad, es decir, comienza a circular el poder y la autoridad.

Cualquier grupo de personas es para la Sinautoría un potencial grupo productor que se otorga a si mismo la autoridad de producir una obra o cualquier bien cultural. No practicamos un concepto de inclusión específica de gente que se incorpora "al mundo o actividades artísticas" de una élite de especialistas. Producimos juntos porque nos necesitamos y queremos conocernos. No existe una película de Cine sin Autor entre especialistas y técnicos de cine. Es indispensable en la composición de nuestras colectividades, que el imaginario emerja de personas no profesionales de la actividad audiovisual. Si no hay personas comunes, no es posible una película de Cine sin Autor.

Nuestra función como artistas o personas del ámbito de la cultura, es, justamente la de romper ese arrogante status de autoridad, elitismo y privacidad, que solemos tener. Entendemos que la autoridad y la propiedad de la cultura y el arte reside en cualquier grupo de personas que se organiza para producirla. Como realizadores de cine nos concebimos servidores públicos al servicio de la buena salud, la digna exteriorización y la decente y profesional materialización de la imaginación social a través del cine.

Practicamos por convicción política un efectivo suicidio autoral, suicidio cultural, renunciando al poder que naturalmente se nos otorga como profesionales y lo hacemos desde el inicio de cada experiencia. No hemos encontrado más eficaz 
gesto para violentar la estructuración social que heredamos, demasiado viciada por el culto del autor y los artistas.

Nuestro gesto provoca una crisis en los roles establecidos, un vacío de autoridad y poder que en la práctica es ocupada inmediatamente por el resto de personas. Matamos a nuestro autor para construir una colectividad.

Como sujeto de poder nos desautorizamos a nosotros mismos como portadores de autoridad para dar lugar a la emergencia de la autoridad común. Sabemos algunas cosas e ignoramos otras, como cualquier persona.

No sabemos entonces de qué puede tratar una película que hemos elegido hacer con un grupo de personas específico hasta que nos ponemos en marcha y el trabajo en común lo va revelando. Solo sabemos que queremos hacerla con esas personas. Elegimos el sujeto con quien queremos trabajar o bien ellos nos eligen, acordamos un formato (la película) como objetivo, pero no realizamos ninguna otra elección de principio.

En lugar de un status de saber elegimos un status de ignorancia. Destruimos nuestra propiedad para constituir una dependencia de los demás. "Si los demás no comparten su imaginario, no habrá película de CsA".

El desconocido, el otro, se vuelve automáticamente potencia frente a este desplazamiento suicida porque se le posiciona como centro fundamental de parte del saber sin el cual se paraliza el proceso de producción.

Se trata de un trastorno de identidades. Nadie tiene, en la dinámica sinautoral una identidad acabada desde la que presentarse y con la que ya viniera, sino una identidad por terminar de construirse con otros y en su potencia productora. Una nueva identidad que trasciende la identidad individual.

De esta manera entra en crisis el antiguo orden por una expresa voluntad política. Es el gesto radical que dinamita el ordenamiento establecido. Sutil. Sin estridencias. Un atentado al orden. Un gesto violento: la desobediencia al orden social de producción jerarquizado, tiranizado por el saber profesional, con claras diferenciaciones de poder excluyentes, con procesos de creación ocultos y privados, con manipulaciones del imaginario de unos sobre otros.

Atentamos así contra las certidumbres que determinan la producción del cine históricamente. Declaramos la nulidad de la propiedad de las funciones profesionales habitualmente vinculadas a su saber. Se sustituyen la autoridad heredada por la autoridad común. Se resetean las relaciones. Las desigualdades de saberes y de experiencia se explicitan para intensificarse. No nos reconocemos todos iguales sino todos diferentes en el concierto de un sistema relacional recordado y según una funcionalidad productiva inmediata: vamos a hacer una película juntos.

Esta crisis abre la posibilidad una nueva situación de participación, horizontalidad, construcción común. Estamos para producir una cosa y nos organizamos en función de ello.

Una vez que cometemos nuestro suicidio, el orden que había se derrumba, entra en crisis y nos preparamos calmadamente para una experiencia real de lo común, un nuevo panorama de relaciones creativas y productivas. 
Se produce un cambio cualitativo en quienes no son profesionales, ni participan del "mundo del arte", donde la autonomía para participar generalmente se activa y las personas comienzan a vivir la creación de la película como una responsabilidad excitante.

\section{La película como despertar organizativo y horizonte utópico útil}

Hacer una película es un horizonte, un lugar de utopías imaginarias personales y colectivas, que, al plantearse como posibilidad, detona la creatividad. Se trata de un formato conocido que contiene en sí un imaginario común, con suficiente fuerza y atractivo para provocar casi instantáneamente la participación social. En general, cuando hemos comenzado procesos, en pocos casos hay que alentar la participación porque la posibilidad de hacer cine nos ha sido negada al común y despierta en sí mismo una enorme curiosidad.

En el imaginario común, una película sigue teniendo mucha fuerza simbólica. Todavía parece mantenerse intacto, a pesar del más de un siglo de cine que llevamos, lo que los cronistas comentan de las primeras experiencias de tomas públicas que hacían los hermanos Lumière en los orígenes del cine: a la gente le causa mucha curiosidad verse en la pantalla.

La película es un cuadro vacío al que dotar de contenido. Siendo una noción que nos es común, se transforma en excusa para la organización social creativa, autorepresentativa, en un horizonte que alcanzar pero indefinido, un contenedor que no tiene límites espacio-temporales y cuyo proceso será ajustado al devenir del grupo generador.

Su existencia determina un sentido a toda la organización. No es una actividad más sino el territorio abierto a la imaginación que para funcionar depende de un primer acto de exteriorización: la película que cada uno lleva dentro y que tiene la oportunidad de exponer, contar y proponer al común. Ése es su contenido particular, su texto privado, su flujo personal de imágenes internas que de una vez, en la primera asamblea vuelca cada persona al común.

Aquí comienza un largo y rico camino de tensión entre lo oculto privado y lo público, lo que las personas se atreven y desean hacer público y lo que dejarán aún sin compartir. No se trata de una terapia donde se exponen problemáticas internas. Estamos en el territorio de la ficción, compartimos imaginarios, provocamos a la imaginación, la gente común abandona la función social espectadora que "el concepto de cine" les asigna para asumir un rol activo. Tan activo que, de no compartir sus imaginarios, no habrá película.

Se entra en un campo de posibilidades imaginativas e interpretativas. Se pacta desde el principio que lo que digan y propongan entra rápidamente en proceso de materialización y deberán no solo defenderlo sino protagonizarlo y ocupar con ello el espacio escénico, entrar corporalmente en las propias propuestas de sus imaginarios. Si no se quiere interpretar en escena, pues se deberá al menos dirigir a otros intérpretes. 


\section{El guión. La generación de narrativas comunes. La ruptura de la soledad imaginaria}

Una vez hecho el contacto y la decisión de trabajar juntos en una película, sin utilizar guión técnico tal como lo concibe el cine, provocamos una situación de narratividad asamblearia donde cada participante, como decíamos, expone su propia película, la hace pública, la defiende, la explica y la comienza a mezclar con las otras películas que, individualmente, los demás participantes irán poniendo en común. El contenido y la forma surgen del debate y la puesta en común de los imaginarios que cada uno trae y está dispuesto a compartir y a integrar.

Es importante remarcar que las personas se han integrado a una colectividad no para abordar una problemática o situación común de tipo terapéutico o social sino para fabricar una película en común. Lo que les une es un futuro productivo, un contenido de ficción a construir y no un pasado que tenga que ser compartido.

En segundo lugar, se remarca que están allí no por alguna capacidad, cualidad o situación específicas, sino por lo que sean capaces de imaginar. Esto provoca un descanso terapéutico que creemos que resulta gratificante, liberador y creativo. En uno de los proyectos que tenemos en marcha desde hace dos años, ahora "Mátame si puedes" web serie, las personas venían de un Centro de Rehabilitación Psicosocial con el que llevan años vinculados. La web serie en que se transformó la película inicial, nunca abordó sus asuntos personales sino que se fue construyendo a partir de los imaginarios que cada quien aporta en cada sesión.

Los asuntos específicos de "salud mental" han sido abordados tardíamente un año y medio después de estar trabajando y por una necesidad práctica: resolver la manera en que nos presentaríamos en las diferentes exhibiciones en salas de cine $\mathrm{u}$ otros sitios.

En Cine sin Autor hemos trabajado durante los últimos 7 años con gente muy diversa y siempre planteamos el mismo esquema de partida: ¿hacemos una película juntos? No importa quien seas, ni tus circunstancias, importa que imaginario seas capaz y quieras exteriorizar y cuánto estés dispuesto a trabajar colectivamente.

\section{Despertar creativo de la autonomía personal}

Esta situación asamblearia, basada en compartir imaginarios y producir un film a partir de ellos, es un ensayo de ruptura del autoritarismo cinematográfico y sus dinámicas generalmente jerarquizadas, que son reflejo de la sociedad y la cultura tal como la hemos organizado.

A medida que avanzan los procesos, quienes continúan, van apropiándose progresivamente del funcionamiento creativo del cine. Aunque no controlen lo técnico. Se avanza lentamente en la autonomía creativa, al comprender por propia experiencia los procedimientos y técnicas del cine.

Nuestras películas arrancan con una pregunta concreta $Y$ tú... ¿qué pelicula harias?...

¿Y tú?... es la pregunta después de un derrumbamiento. Y ahora que ha quedado en crisis el sistema de relación social y el modo de ejercer el poder y la 
autoridad...Y tú... ¿qué haces con esto qué ha pasado? Y tú ¿qué opinas? Y tú, individualmente ¿cómo te posicionas ante la nueva situación?... Y tú ¿qué película harías? Ahora que la situación te ha ubicado ya no como "espectador" sino como potencial productor.

Es el primer abordaje de posibilidad. El ingreso en el territorio de lo inédito: que una persona cualquiera ajena al sector cinematográfico, pueda imaginarse como director, guionista e intérprete de un film, abandonando su antiguo sitio espectador.

Es una provocación a su identidad espectadora que se ve violentada a tener que pasar a la acción, a imaginar, a proponer, a agenciarse de una situación que la crisis le presentó como territorio de nuevas posibilidades, como situación inédita, como potencia inhabitual: la de hacer una película.

En este arranque del proceso hay una inversión suicida del grupo que ejerce el poder y la autoridad productora: de la posición de jefatura, de dirección, de mandato, de autoridad, nos desplazamos otra vez a esa actitud de servicio, de dependencia, de ignorancia, que mencionamos antes.

"En una película que haríamos juntos, qué película harías tú si nosotros nos ofrecemos como servidores y posibilitadores de tus ideas"

Una vez hecho el posicionamiento individual al que lleva la pregunta, lo que sigue es un nuevo desplazamiento: de lo individual a lo colectivo. $Y$ nosotros ¿qué película haríamos?, solemos preguntar luego.

La pregunta abre un nuevo campo de posibilidad. El individuo, en el primer movimiento, salía o era sacado de su antiguo sistema de relacionamiento social productivo "Yo no sé, yo no hago cine, soy espectador..." suelen responder muchas veces las personas. Habituadas a no tener posibilidad alguna de ejercer su derecho a la producción, de pronto se ve inmersas en la obligaciónposibilidad de posicionarse y responsabilizarse individualmente sobre la producción de su propia película. Cuando las personas dan ese quiebre, generalmente abandonan todo tedio y aceptan la oportunidad.

Luego, la persona es invitada, así, a asumir otro desplazamiento: abandonar la posición individual y reposicionarse sobre un funcionamiento colectivo. ¿ $Y$ ahora que formas parte de un nosotros? ¿Cómo relacionas tu imaginario con el de los demás? ¿Cómo gestionas tu verdad individual en el concierto de las verdades comunes?

Una vez más no estamos hablando de asuntos directamente biográficos sino de la articulación de sus imaginarios.

El funcionamiento colectivo supone otra provocación al rol social determinado por el cine. Comúnmente nos concebimos solos o en entornos colectivos que se nos presentan con poca capacidad de cambiar de rol social y productivo. La familia es un entorno de colectividad elegida por algunos miembros pero no por todos. Los hijos nunca eligieron pertenecer ni funcionar en el entorno familiar. El entorno laboral, es también colectivo pero quienes diseñan el sistema de relación suelen ser sus directivos y no el conjunto de trabajadores y trabajadoras. Los sistemas de relación social en conjunto se pueden analizar desde el punto de vista 
de la autoridad y el ejercicio del poder y nos encontraríamos con una infinita amalgama de sistemas, en un alto porcentaje, de corte autoritarios e impositivos.

\section{Crisis y reordenamientos de los roles sociales}

Ya habíamos dicho que en Cine sin Autor se redefine, como primer gesto de suicidio autoral, la función de los profesionales como figuras de autoridad y poder de decisión, poniéndola a operar como una función de servicio al imaginario no profesional.

A partir de este primer gesto comienza un estado de indefinición que en cada sesión se hará patente según la materialización del imaginario avance. Muchas veces, hay personas que al principio permanecen calladas o poco participativas, pero que más tarde tienen diferentes despertares y empiezan a ocupan roles interpretativos, a dirigir una escena o involucrarse en otras tareas.

La circulación permanente de las funciones, va afianzando a cada uno en sus intereses particulares pero en función de las necesidades prácticas colectivas.

Concebimos el concepto de tiempo social del Cine sin Autor como antípoda del tiempo de producción del Cine convencional. Esto es determinante para asegurar una sana vinculación con la fabricación de las películas.

La producción del viejo cine, obligó siempre a que la realidad se adaptara a una planificación profesional, muchas veces determinada por el presupuesto que se tiene o por el tiempo de producción del director o equipo. Pero hay que decir que la cultura en general suele funcionar bajo los tiempos de los profesionales, gestores, artistas que son los que determinan el ritmo de producción.

El trabajo sobre el tiempo social como guía, es decir, el tiempo que respeta los ritmos, las circunstancias, los propios procesos de las personas no especializadas, permite emerger situaciones que no se pueden concebir en el cine más convencional.

Hay personas que luego de haberse ido en las primeras sesiones por asuntos personales, han vuelto un año después sabiendo que la película había avanzado mucho y que el proceso estaba en marcha. Nuestra dinámica permite la entrada o readmisión de cualquier persona en cualquier momento si el proceso sigue activo.

Hay que anotar que esos tiempos prolongados son, así mismo, una tensión dificultosa ya que supone mantener en activo a un equipo de profesionales y no siempre es fácil ni se tienen los medios.

Varios procesos que tuvimos que abandonar a lo largo de estos años, se debieron justamente a esa imposibilidad del equipo técnico y no de las personas que participaban.

\section{Los cuerpos en la ocupación del espacio escénico}

La experiencia nos fue llevando al criterio metodológico de que luego de no muchas sesiones de narratividad, debemos pasar directamente al rodaje. El rodaje es una de las partes más ocultas del cine y de la que menos participan las personas comunes y a la vez, es posiblemente lo más intenso y excitante de la producción de una película. 
Esta premura en pasar a rodar aumenta el nivel de responsabilidad. "Si has puesto tu imaginario e imaginas un personaje, en próxima sesiones ocuparás el espacio escénico para interpretarlo o dirigirás a otra persona para que lo haga por $t i$ ". No hay escapatoria. No es que se obligue a alguien a participar porque "la participación es buena en sí, terapéutica o entraña alguna bondad específica en la normalización o integración social". La persona tendrá que ponerse en escena o poner en escena lo que imaginó por un problema metodológico que compete a la seriedad del trabajo: nadie mejor que ella conoce el contenido que ha compartido y la manera en podría representarse.

Damos un paso más. Ahora se trata de una operativa que ocupa el espacio y en donde las personas deciden la localización de la escena o asunto que habrá de filmarse.

El concepto de PLATÓ-Mundo, que mencionamos antes, se hace aquí patente. Lugares públicos, casas privadas, calles, tiendas, parques y cualquier sitio habitual de los participantes, se convertirán durante los tiempos de rodaje, en un plató. Un sitio habitual será visto con otros ojos y hay que buscarle su potencial fílmico. Abrimos con ello un territorio nuevo de relaciones. Las personas entran en contacto a través de algunos de los lugares habituales que se ofrecen para la realización de las escenas propuestas. Lugares donde re-presentar y representarse escénicamente como parte de una ficción que se piensa en común.

Cuando comienza el rodaje, comienza la movilización, la ocupación espacial de los sitios, el redescubrimiento de lugares frecuentados cuya mirada es revisada con la perspectiva de convertirlo en ficción y sacar su potencial cinematográfico.

Además de ésta re-significación del espacio, el rodaje constituye una apertura a la gestión de la apariencia, la posibilidad de tras-vestirse, de ensayar identidades, de utilizar el cuerpo, la voz, de enmascararse a través de la ficción, de liberarse en una improvisación o disciplinarse en el cumplimiento de pautas planificadas o acordadas por todos.

Aunque nunca antes hubieran participado de un rodaje, luego de vivirlo, las personas entienden con rapidez los principios que lo constituyen.

Las ideas alguna vez imaginadas, se fijan a través del rodaje. Una vez en la pantalla como parte de la ficción común, la persona vuelve a revivir, de manera indirecta aquella experiencia. Las imágenes de una película de Cine sin Autor, dejan de ser para sus participantes, ese flujo audiovisual que discurre en el cuadro del que nunca descubren el espesor de su producción. Ahora, lo que ven en la pantalla tiene memoria, memoria productiva.

La tecnología de registro (cámaras, luces, sonido) gestionadas en principio por los técnicos, está abierta al relevo de quien sienta interés por cualquier otra función de las que está viendo ocurrir. Los saberes y las preguntas se comparten haciendo la propia película y las responsabilidades pueden rotar.

Es más común en las personas jóvenes el uso desprejuiciado de la tecnología de registro y dónde más posibilidades de hacer circular la propiedad de los medios técnicos. 
Un rodaje no es ni más ni menos, que el registro de imágenes y sonidos de una situación o representación que hacen unas personas delante de la cámara. Se filma siempre una actuación.

\section{La escritura fílmica en común}

El Montaje generalmente lo hacemos los técnicos para ofrecer una primera versión del material filmado de manera más o menos inmediata. Se trata de un montaje provisorio solo a los efectos de que se pueda ver la ilación de ideas que se logró en el rodaje, con el fin de discutirlo colectivamente.

Cuando la situación lo permite, hacemos el montaje en directo, con las personas delante. Las exhibiciones de estos materiales provisorios se someten a opinión y las decisiones se toman en colectivo. También las sesiones de postproducción de imagen y sonido son abiertas y el colectivo irá interviniendo y modificando la obra que está produciéndose.

La experiencia del montaje es un momento revelador. Es allí donde se comienza a urdir la trama narrativa común a medida que avanzan los rodajes.

Se abandona el territorio de la palabra como herramienta de comunicación y debate para centrarse en lo que empieza a ocurrir en la pantalla. En ella se irá organizando el material rodado, en su línea de tiempo. Los contenidos ya no son psíquicos sino audio-visuales y ya no son privados sino exteriorizados, públicos, y cualquiera puede verlos, participar y opinar sobre ellos. Es común, que en estas exhibiciones se incorpore gente cercana a alguno de los participantes o interesados por el proyecto, que pueden ver el material en pantalla en plena gestación y que muchas veces opinan y sugieren ideas que luego se incorporan.

De esta manera, el cine empieza a generarse delante de las personas. Deja de ser aquel asunto mágico e inexplicable de las salas de cine.

El hábito de verse interpretar es de por sí terapéutico. No toda la gente entra inmediatamente en una buena relación con su imagen. Hay personas que optan por no aparecer durante un largo tiempo mientras participan motivadamente viendo a los demás hacerlo. La mayoría acepta salir y a medida que se ve en los sucesivos visionados, va aceptándose y a la vez modificando sus gestos en los rodajes. La voz es recurrentemente el elemento más extraño para quien nunca antes había escuchado con atención un registro de su voz. Esta reacción es justificable cuando sabemos que estamos más familiarizados con imágenes de nosotros mismos que con registros de voz dado el estado actual de los dispositivos.

En general, a lo largo de los 10 proyectos que hemos realizado en estos últimos 7 años, la mayoría de personas siente una gran curiosidad y motivación por verse y participar activamente como intérpretes y guionistas de sus propias ficciones.

Aparte de ese trabajo casi terapéutico con la propia imagen, el montaje puesto en colectivo introduce a las personas la narración, la gramática, la ingeniería de los discursos fílmicos.

El montaje posibilita un momento más de la disolución de las fronteras de lo individual y lo colectivo. 
A medida que avanzan las sesiones de montaje, se deben encontrar razones claras y contundentes para progresar en el sentido del material.

Cada persona, de alguna manera, ha afirmado determinados contenidos individuales que ha querido filmar y ha entrado al debate común a través y en relación a ellos. Su contenido sigue siendo suyo pero a la vez se contamina, se hibrida con el resto de contenidos.

En varios testimonios grabados al final o en mitad de los procesos hemos recogido la opinión de participantes que confiesan que no pueden recordar cómo se resolvió una idea de guión o algunas situaciones de rodaje o montaje. Pueden recordar el conflicto pero no quién exactamente aportó finalmente la deriva narrativa o la resolución de la escena. Hay personas que al cabo de un tiempo largo de trabajo no recuerdan cuál era su postura personal al principio de todo, o qué película habían sugerido, lo que evidencia que el imaginario individual sufre diferentes alteraciones de expansión, disolución, contaminación, recortes, complementación, en su contacto con lo colectivo y en la disolución de lo individual al contacto con el resto de imaginarios.

\section{Responsabilidad común sobre la gestión y el uso}

Quizá una de las partes más dificultosas en el cumplimiento de nuestros objetivos sea todo lo posterior a la realización propia de la película.

Si ya las personas no especializadas solían y suelen, en muchos casos, desconocer los procesos de fabricación de una película, la democratización de la circulación y gestión que pretendemos (gestionar su circulación, difundirla, acompañar sus presentaciones) resultan de lo más ajena.

Las exhibiciones de Cine sin Autor más importantes son aquellas que reúnen lo que denominamos Espectador Primero o Presente (quienes han participado de alguna manera en la fabricación de la película) con el Espectador Remoto (quien no ha participado en la producción -el viejo espectador del cine-). La exhibición es un momento de intercambio del trabajo y una oportunidad para que un público más lejano encuentre un momento de contacto con el material y pueda incluso unirse al proceso de fabricación de la película que se le ha mostrado.

Como en el resto de etapas del proceso, la intención es democratizar las tareas de circulación, distribución, exhibición etc. Es, una vez más, la propia colectividad la que determina el modo de hacerlo y la que tiene la oportunidad, si así lo desea, de defender la película en caso de exhibición, participación en festivales, muestras, etc.

\section{Conclusiones}

Hemos querido en este artículo, contar con sencillez, algunas de las ideas principales que sustentan la teoría y práctica del Cine sin Autor, pensando en que, posiblemente, para la mayoría de los lectores de esta revista, sea el primer contacto con nuestro trabajo. 
Orientando las conclusiones al punto de reflexión del arte, la educación y la integración, el cine se ubica en un territorio posiblemente más complejo, ya que la propia discusión entre arte y negocio, forma parte inseparable de su historia.

Hemos preferido una interpretación histórica que pone el énfasis en lo que sin duda fue primero en el nacimiento propio del cine: "una actividad de gente que se organizó en torno a un negocio estético: la fabricación y comercialización de películas".

En ese sentido, en lo que hemos hecho hincapié es en la capacidad del cine como actividad que produce películas y piezas audiovisuales, rescatándolo como un "entorno de producción" que en lugar de ser exclusivo de una minoría, podamos constituirlo como "un entorno abierto a cualquier persona". Esto convierte a la actividad cinematográfica, no en una herramienta discursiva, sino en un ámbito de trabajo y organización común, de tal modo que quien esté en una película de Cine sin Autor, trabaja, se organiza, tiene tareas, opina, se compromete, acepta unos hábitos de actividad, aprende sobre la marcha, exterioriza su imaginario, se compromete con horarios, es testigo de todo el proceso, se involucra en aquellas partes que le interesen más, reacciona emocionalmente, cuenta lo que quiere, y sobre todo, aporta las ideas, el imaginario y la interpretación escénica de la película.

No concebimos la creación de una película como una actividad con objetivos terapéuticos, participativos o expresivos determinados. Cualquier actividad los tiene y más si es una actividad artística.

Para los técnicos y desarrolladores del Cine sin Autor, cada película ha sido un encuentro social con gente desconocida, un viaje hacia territorios humanos y grupos que no forman parte de nuestro ecosistema relacional, una manera de salir de nosotros mismos y de nuestros guetos profesionales y reducidos espacios de convivencia.

Y para los no especialistas, sabemos que las películas de Cine sin Autor han sido también un encuentro inesperado e inédito que los transportó a un mundo creativo insospechado, a formas de expresión impensadas, a intensidades emocionales nuevas, a la exteriorización de ideas que estaban escondidas, a responsabilidades que no habían tenido, así como, igual que en nosotros, a un viaje a nuestro pequeño territorio profesional que de otra manera no conocerían.

Una película de Cine sin Autor es un encuentro humano productivo para borrarnos las diferencias y la indiferencia que generalmente nos acompaña.

Ningún proyecto ha sido fácil pero todos han sido fascinantes, vitales, profundos y sísmicos para todas y cada una de las personas que participamos en ellas. 


\section{Referencias bibliográficas}

AIDELMAN, N. y DE LUCAS, G. (2010):Jean LucGodard. Pensar entre imágenes. Barcelona. Intermedio.

MORIN, E. (2011) El cine o el hombre imaginario. Barcelona. Paidós.

TUDURÍ, G. (2008) Manifiesto de Cine sin Autor 1.0. Madrid. Centro de Documentación Crítica.

TUDURÍ, G. (2013) La Politica de la Colectividad. Manifiesto de Cine sin Autor 2.0. Murcia. Servicio de Publicaciones de la Universidad de Murcia. 